\section{Humus Manufacture}

$A^{\text {Gind }}$ RICULTURE in India is by far the main occupation of its teeming millions, and it is a form of agriculture which has not as yet been greatly modified by the impact of British administration, or markedly influenced by the development in scientific crop-production. The cultivator and his family, equipped with little but oxen and abundant leisure, wring a scanty existence out of a smallholding, which may be so small that the average for a province (U.P.) is only about $2 \frac{1}{2}$ acres. The admirable work of Mr. A. Howard, when director of the Institute of Plant Industry at Indore, in the advancement of Indian agriculture is well known. It was his aim to bring about a revolution in crop production by the gradual introduction of intensive methods, to raise production all over India, in dry as well as irrigated areas. Through such increased production, he hoped to provide for the social and material betterment of the rural population.

The most important limiting factor in erop production in India is unquestionably the supply of organic matter to the soil as humus, which in turn supplies the crop with the necessary nitrogen. In a lecture entitled "The Waste Products of Agriculture" delivered on November 15 at the Royal Society of Arts, Mr. Howard dealt with the so-called 'Indore' process for the continuous manufacture of humus material, by means of which the waste products of the farm are utilised, and their valuable constituents made available for the nutrition of crops. After mentioning first the various directions in which added humus influences soil fertility, he described the "humus factory" constructed by him at Indore and copied in many other parts of India, and indeed to some extent in Africa too.

In effect, Mr. Howard's process is the formation of a glorious 'shepherd's pie' of all decomposable material on the farm--weeds, cotton and other stalks, green manures such as sann hemp, cane trash, fallen leaves, etc. The significant part of the process lies in the fact that the humus factory adjoins the cattle shed. The cattle stand on an earth floor which absorbs the urine. The vegetable wastes are used as bedding for the cattle, and next morning this bedding is moved to shallow pits in the factory together with "at least a quarter of the cattle dung". (This commodity is too valuable as a fuel to be squandered in the production of fertiliser.) From time to time the earth floor of the shed is dug up and replaced. The urine-impregnated earth is ground up and carefully stored. Portions of it are sprinkled over the vegetable wastes in the pits, and the whole mass moistened with a slurry made from water, wood ashes, urine earth and an inoculum taken from an older pit. Thereafter the production of a satisfactory humus material depends upon proper management. Subsequent waterings at frequent intervals are most important, otherwise decomposition ceases. Complete turning must be carried out several times. At the end of three months, a brown-black product is obtained ready for use in the field.

The process is in effect a refined form of composting as practised by Chinese cultivators for centuries. It is now known that for the satisfactory decomposition of cellulose materials a certain quantity of microbial nutrients must be present, the chief of which is nitrogen, for conversion to microbial protoplasm. There is indeed a definite and ascertain. able ratio between carbonaceous material decomposed and nitrogen utilised. Most plant materials other than green fresh tissues have a carbon-nitrogen ratio much lower than that necessary for their decomposition. The urine-earth and dung supplement the supply, and so facilitate decomposition. While in practice and from experience it may be possible to judge approximately the relative quantities necessary, the Indore process is not necessarily an economical one so far as nitrogen is concerned, or a particularly controllable one. However, it unquestionably meets the needs of Indian agriculture. There is no cost apart from labour and, on the family small-holding, this item disappears. Indeed, according to Mr. Howard, "The economies of the subject in reality concern the transformation of a portion of the abundant leisure time of the cultivator and of his family into valuable humus".

Apart from utilising vegetable wastes, the process has been modified for the treatment of sewage and municipal refuse, and at Indore City the waste products of 60,000 inhabitants have been dealt with very satisfactorily in this way. This is a more healthy and economic method than the trench system ordinarily employed in India.

The manufacture of humus on the same lines might be possible even where there is not an abund. ance of labour running to waste as in India, and, according to Mr. Howard, has been in unconscious operation on the grasslands of England, where the well-known effect of the droppings of cattle in stimulating the growth of grass appears to be due in part to the conversion of undecayed vegetable material in the sod to humus by reason of the nitrogen of the dung. In his words, "the chemistry of the cow-pat remains to be written".

\section{A. Geoffrey Norman.}

\section{University and Educational Intelligence}

CAMBridge.-The Raymond Horton-Smith prize for $1932-33$ has been awarded to G. D. Kersley, of Gonville and Caius College.

The Governing Body of Emmanuel College is inviting applications for an extermal research studentship which will be awarded in July 1934. Applications (with evidence of qualifications, etc.) must be sent to the Master in time to reach him not later than June 30. Preference will be given to candidates who have already completed one, but not more than two, years of research. The studentship must be held at Emmanuel College, has a maximum annual value of $£ 150$, is awarded and normally held for two years, but may be renewed for a third. The student. ship is not tenable by a woman or by a graduate of the University of Cambridge.

LEEDs.- - The title of emeritus professor has been granted to the following, who have recently retired from the staff of the University : Prof. A. F. Barker (textile industries); Prof. J. F. Dobson (surgery); Prof. W. Garstang (zoology); Prof. J. Strong (education); and Prof. R. A. Veale (therapeutics, pharmacy and materia medica).

LoNDON.-The following degrees have recently been awarded: D.Sc. in entomology to T. A. M. Nash (private study) for published work entitled (1) "The Ecology of Glossina morsitans, Westw., and 
two possible Methods for its Destruction", (2) "A Contribution to our Knowledge of the Bionomics of Glossina morsitans", (3) "The Relationship between Glossina morsitans and the Evaporation Rate," (4) "Note on the Discovery of some Rock-Paintings near Kondoa Irangi in Tanganyika Territory" D.Sc. in chemistry on L. J. Burrage (King's College) for thirty-one works on "The Sorption of Gases and Vapours by Porous Solids". D.Sc. in embryology on Aziz Girgis (University College) for a thesis entitled "Development of the Heart in the Rabbit" (Proc. Zool. Soc., Oct. 1930 and June 1933).

THE Institution of Naval Architects is offering the following scholarships for competition in 1934: naval architecture, Elgar scholarship ( $£ 130$ a year for 3 years) and Vickers-Armstrong scholarship (£150 a year for 3 years); marine engineering, Yarrow scholarship ( $£ 100$ a year for 3 years). Particulars can be obtained from the Secretary of the Institution, 2, Adam Street, Adelphi, London, W.C.2.

The Le Play Society is arranging a visit to Rome during the Christmas vacation under the leadership of Prof. Hamilton Thompson. This visit will be of interest to students of medieval history, while classics scholars will have the help of local specialists both in Rome and Ostia. Further information can be obtained from Miss Margaret E. Tatton, The Le Play Society, 58 Gordon Square, London, W.C.1.

THE Association of University Teachers has an International Relations Committee which has organised visits to French, German and Scandinavian universities. Last June it convened a conference at Exeter attended by representatives of the staffs of universities of Germany, Holland, Sweden, Norway, Poland, Italy, Ireland and the United States. Some observations on this conference appear in the October number of the Universities Review. The proceedings brought out very clearly a divergence of point of view between universities which, like those of Great Britain, are still dominated by what may be described as liberal ideology and those in which the traditional right of universities to liberty of thought and teaching has given place to a nationalism, narrowly economic, possessive and truculent, prepared to subordinate everything to political ends. Far from being discouraged by the manifestation of such discordant views, the Association, believing that the maintenance of personal contacts with foreign universities is all the more to be desired by reason of such differences, is proposing that the summer meeting of its Council shall, when convenient, be given a definitely international bias by the presence of representatives from foreign universities, and the allotment of some of the time to the discussion of some general academic question calculated to be of interest to them. The same number of the Universities Review has an article by C. W. Guillebaud of St. John's College, Cambridge, describing the activities of the International Student Service, an organisation with headquarters at 13 Rue Calvin, Geneva, and a London office at 3 Endsleigh Street, W.C.1. Formed in 1926 to carry on the constructire work initiated by "European Student-Relief" in 1920, this body has of late been busying itself with the relief of distress among Jewish, socialist and pacifist refugee students from Germany.

\section{Harmattan \\ Calendar of Nature Topics}

With the approach of winter in the Sahara, the air cools rapidly, barometric pressure rises, and the north-easterly wind which is normal in northern subtropical latitudes is re-established along the coast of West Africa from French Guinea to the Cameroons. This dry, cool, north-easterly wind, known as the Harmattan, is a great relief after the moist heat of the summer monsoon, and from its healthful effects it is locally termed 'the Doctor'. Originating in the desert, it carries a great amount of impalpable dust, which often forms a thick haze, sufficient to hide the sun and impede navigation on the rivers, and penetrates into houses through every crack. The Harmattan generally begins towards the end of November and continues until about the middle of March, interrupted occasionally by short periods of variable winds.

\section{Autumn Bird Migration at Lighthouses}

During autumn and winter, heavy mortality of bird migrants occurs at some lighthouses, and though the fatalities have been considerably lessened at certain British lighthouses through the fitting of special rest-perches by the Royal Society for the Protection of Birds, numerous records are still obtained at this time from birds killed through colliding with the glass of the lantern. In September $1929,1,237$ birds of 55 species, chiefly warblers, were picked up at the Long Point Lighthouse, Ontario, a 1,000 candle power light (Auk, Oct. 1930). The first Irish record, and first autumn record for the British Isles, of the sub-alpine warbler, was obtained from the Hook Tower Lighthouse, Co. Wexford, in September 1933 (British Birds, Nov. 1933). In fog during November and December, numbers of fieldfares, starlings, redwings and curlews are usually reported from certain British lighthouses, and in 1932, the Skerries reported pied flycatcher and yellow wagtail as rare visitors on the southward passage, while later, on the gallery, were noted such non-perching birds as water-rails, turnstones, lapwings, skylarks and whimbrel ; snipe and woodcock were seen on two occasions. At the Spurn lighthouse on October 12-13, 1931, the perches were packed with thousands of starlings. The erection of perches at the British lighthouses costs $£ 60-£ 100$, the annual maintenance is $£ 15-£ 20$, and the perches are usually left in position from the autumn until the following June.

\section{Autumn and Winter Movements of Moose}

At the end of the summer season, the elk or moose (Alces americana), the largest living representative of the deer family (Cervidæ), move away from the neighbourhood of swamps, rivers and lakes in North America for their winter quarters in the higher grounds. This is necessitated by the dense, rank grass growth of summer no longer affording full protection, and they seek the forests, where small parties may take up quarters in what is termed a 'mooseyard'.

The destruction of the elk is almost as tragic a story as that of the bison, but herds numbering about 17,000 find sanctuary in Yellowstone National Park; and a few miles south, at Jackson Hole, as many as 20,000 have been counted in winter. The 